\title{
COMPETITIVENESS OF CZECH ENTERPRISES: WHAT AFFECTS THE PERFORMANCE OF THE ENTERPRISE?
}

\section{Petr Suchánek, Jiří Špalek}

Ekonomicko-správní fakulta Masarykovy univerzity, katedra podnikového hospodářství, katedra veřejné ekonomie, Lipová 41a, 60200 Brno (Petr.Suchanek@econ.muni.cz; Jiri.Spalek@econ.muni.cz)

Abstract: This article is based on an empirical survey performed by the Research Centre for Competitiveness of the Czech Economy in 2007. We analyzed a sample of 432 companies. The main objective of the article is to formulate the factors which decrease the probability that a given company will be rated as competitive. Using advanced statistical methods (particularly statistical method of pattern recognition developed by UTIA ČSAV and modified in a special way for the purpose of our research) we formulate 20 qualitative characteristics, which can cause uncompetitiveness of the selected firm. These characteristics are then discussed and basic recommendations are drawn.

Key words: Competitiveness, enterprise cluster analysis, stakeholder

Anotace: Článek vychází z empirického šetření provedeného Centrem pro výzkum konkurenceschopnosti v roce 2007. Základem je vzorek 432 českých průmyslových podniků. Cílem př́ispěvku je nalézt faktory, které snižují konkurenční schopnost daného podniku. Výchozím kritériem konkurenceschopnosti je finanční úspěšnost daného podniku, přičemž podniky jsou na základě shlukové analýzy rozděleny do dvou skupin. S využitím statistické metody rozpoznávání obrazců vyvinuté a speciálně pro daný výzkum upravené pracovištěm UTIA ČSAV formulujeme 20 faktorů nekonkurenceschopnosti. Tyto faktory dále diskutujeme a na jejich základě vyvozujeme doporučení pro české podniky.

Klíčová slova: Konkurenceschopnost, podnik, shluková analýza, stakeholder

JEL classification: G30, M21

DOI: $10.2478 / \mathrm{v} 10135-009-0003-6$

Národohospodářský obzor - Review of Economic Perspectives

ISSN 1804-1663 (Online), ISSN 1213-2446 (Print)

http://nho.econ.muni.cz/en

(C) Masarykova univerzita 


\section{COMPETITIVENESS OF CZECH ENTERPRISES: WHAT AFFECTS THE PERFORMANCE OF THE ENTERPRISE?}

\section{Petr Suchánek, Jiří Špalek}

\section{Introduction}

This article is based on an empirical survey performed by the Research Centre for Competitiveness of the Czech Economy in 2007. The main object of the article is competitiveness of companies. It is based on the premise that competitiveness is a qualitative property of a company, which is reflected in its financial performance, assuming that the more able a company is to compete, the better performance it reaches.

In defining competitiveness, we can start from both macroeconomic and microeconomic interpretation of this concept. Both views, however, are interrelated, because it can be claimed that competitiveness of individual firms - i.e. microeconomics - affects and determines the competitiveness of the economy as a whole - i.e. macroeconomics (in greater detail see Šiška, 2005). The concept of competitiveness has a microeconomic character and therefore a competitive company is able to succeed in competition with its rivals (Slaný, 2006). This general concept can be further developed and so competitiveness can be defined as a quality, which enables an entrepreneurial subject to succeed in competition with other entrepreneurial subjects (Pitra, 2001). However, this concept does not explain how a firm can succeed on the market. It is obvious that if a company is to succeed on the market then it must have a certain advantage in comparison with its rivals and must be capable of exploiting this competitive advantage to outperform its competitors. The question is how this ability to compete should be rated.

In order to be able to enter the competitive relationship, a firm has to meet two basic conditions: to have a competitive advantage and competitive interest (must have drive to compete) (Mikoláš, 2005). When exploring competitiveness, it is necessary to focus not only on the market analysis, or a firm's position in the market, but also on the analysis of internal and external competitive capabilities and prerequisites (Mikoláš, 2005).

Competitiveness of a firm is linked with its potential, the quality that could be developed to make it successful. This potential serves as a basis for outlining the firm's vision and mission -that is what the firm plans to achieve. On the vision hinges corporate strategy which says how the firm is going to attain this vision in order to fully utilize its potential. Due to the fact that the firm's objectives, its vision and potential must be expressible in financial terms, we offer the possibility to establish competitiveness by financial tools

Competitiveness is a sort of image in the perception of customers, workers, suppliers etc. (so-called stakeholders). Therefore it is closely linked with the value of the company (Mikoláš, 2005). It is this value generated by a company that reflects its competitiveness as a degree to which the vision is attained or potential of the firm is exploited. In such a way competitiveness is a precondition for financial performance and it holds true that if 
a firm is able to compete, it is also high-performing. Performance is understood as the value volume, which a firm generates over a certain period of time (Šiška, 2005).

It is assumed that a high-performing, efficient company will be qualitatively different from a low-performing, inefficient one. In other words, it will have different parameters (characteristic features) of researched qualitative variables. The characteristics are based on the stakeholder model of the corporation used by Donaldson and Preston in which a corporation can be characterized from the point of view of various interest groups. Furthermore, it is assumed that the principal groups are formed by owners, employees, creditors (investors), general public (state), customers and suppliers, to name the primary stakeholders (Donaldson, Preston, 1995). Individual groups are then analyzed according to their specific and particularly qualitative characteristics (see Blažek, Částek, 2009).

Based on the above statements, account data were collected and then financial performance of firms was determined, using a chosen instrument of financial analysis. Subsequently the firms in question were clustered using the method of cluster analysis according to their financial performance. Then the qualitative characteristic of factors was ascertained by the questionnaire method. The questionnaire included the factors which could influence competitiveness of the firms and which were derived from the stakeholder model.

The article shows the results of experiments that lead to finding those characteristics (by the questionnaire method) which distinguish low-performing firms (found by the financial analysis and then identified by the cluster analysis) from other companies. In order to quantify the characteristics of individual factors, their values must be determined using crosstabs and comparison of means. Thus it can be established which characteristics are typical for uncompetitive firms as well as what values they acquire.

The focus on uncompetitive firms is primarily determined by the fact that they stood out in the cluster analysis as a clearly identifiable and homogeneous group (see Fig. 1). The aim of this article is to identify the factors and their characteristics, which are typical for uncompetitive firms, and then to quantify them. Thus feasible recommendations can be proposed and discussed on the basis of the characteristics, which could help improve the position of the uncompetitive firms within the framework of Czech companies.

The article is organized as follows: First section briefly summarizes method and technique of basic statistical set construction. The second section presents methodology employed in our research - cluster analysis, statistical pattern recognition and bivariate statistics. Main results can be found in third section and are discussed in forth part of the paper.

\section{Research sample}

The population for the Centre's survey included all industrial companies from various regions in the CR. The basic set was then generated by reducing the available set on the basis of several limiting criteria:

- number of employees (higher than 50),

- availability of economic data,

- firm domicile is the CR, 
- $\quad$ legal form (joint stock company or limited liability company),

- $\quad$ turnover per employee (over CZK 1 million = about EUR 34 500),

- $\quad$ sector (industry without agriculture and fishing industry, trade and services without the public sector and activities of households).

It is a case of stratified sampling, in which the basic set was constituted by 2817 companies that met the above criteria. All companies in the basic set were addressed by the researchers but in the final phase data were gathered about 432 firms, i.e. $15,3 \%$ of the basic set, using questionnaires. It included 59 structured questions focused on finding out firm's characteristics. The characteristics were chosen in accordance with the traditional stakeholder model (Blažek, 2005).

Responses in the questionnaire are rather qualitative in their character and they were completed by a quantitative description of the firm based on its financial statements (balance sheets and profit and loss accounts). The objective was to collect information about some basic financial indicators of the firm in question from the past five years. Because financial data of firms are published continuously, it was often necessary to use several databases that contain balancing of books of Czech companies. ${ }^{1}$ Despite the procedure several firms were left with incomplete series of account data. Therefore the missing values were modelled for further analyses (see Šiška, 2008).

\section{Methodology}

The principal premise of our research was a related identification of factors causing (un)competitiveness by using statistical methods. In such a manner, the results can be based on the quantitative analysis of data and do not include any value or a priori judgments. The reason was an effort to be as objective as possible in describing the current situation of Czech industrial companies. ${ }^{2}$

\section{Cluster analysis}

The objective of the research was to divide the chosen companies into efficient (competitive) and inefficient (uncompetitive). For this purpose the cluster analysis method was applied, because it classifies the companies into certain (eligible) number of disjunctive groups called clusters. Cluster analysis has been performed by the nearest centres method (K-means cluster analysis), which classifies individual companies into relatively homogeneous groups (clusters) as based on the minimum intercluster distance of the particular cluster members (minimum distance is derived from Euclidean metrics and in fact it means a minimum sum of squares). Thus, the resulting groups are made of the companies, which show the best match. The least distance identifies the smallest scalar distance of given vectors. In order to ensure a full comparability, individual coordinates (indicators) must be standardized before proceeding to the cluster analysis. So-called z-scores were applied to the standardization (more in Blažek et al., 2007, chap. 12).

\footnotetext{
${ }^{1}$ We have used mainly ALBERTINA database and the commercial register of the Ministry of Justice (www.justice.cz).

${ }^{2}$ Since we classified concrete firms into groups according to their performance, our database was made strictly anonymous. Our goal was not to find concrete competitive or uncompetitive companies but rather to find reasons for being a part of the given group.
} 
Two indicators are chosen as explanatory variables - ROA and interannual growth of assets - and they are computed for the period of 2002-2006. In this part the results are taken from the publication of Šiška (Šiška, 2008). As two indicators are chosen, each company can be defined by a vector having the values of these indicators (with 10 coordinates in total). At the same time the vector is the basis of generated clusters. ${ }^{1}$

\section{Statistical pattern recognition method}

In searching a vector of the variables that distinguishes individual groups (clusters) of companies, a unique method in the area of statistical pattern recognition was applied, which enables to take into account sophisticated statistical relations between studied responses (in the questionnaire survey) in a better manner than the classic bivariate analysis. As stated by the authors of this method ,methodology of dimensionality reduction in decision making of classification type (or the methodology of selecting the most informative features) is so extensive and mathematically demanding that its more detailed explanation is beyond the scope of this contribution" (Blažek, 2008). For this reason this article only summarizes basic principles of this method without its formalized mathematical description. Its principles and the mode of application to our task are presented by Pudil, Somol, 2008, in greater detail Pudil, Somol, 2006. These publications are also used for outlining the essential description of the method in the following paragraphs.

The method developed by UTIA ČAV Praha (below referred to as the UTIA method) is based on the method of forward floating selection. For the purpose of our analysis, the classifier K-Nearest Neighbors (kNN) was chosen, which is capable of solving the compromises that must be taken into account: it is non-parametric (we do not include additional assumptions, which is suitable for the type of investigated data), easy to implement and its decision-making capability makes it one of the strongest available classifier. Although it is computationally intensive and requires a big memory capacity, it does not pose any problems, since no interactive response is required in this case. The issue of generalization or classification of unknown data does not cause serious complications because of the task nature.

The principle of the kNN classifier can briefly be summarized as follows: let us suppose that our objective is to classify a sample when we have a training set of samples with known assignments to appropriate classes. We evaluate the distance (e.g. Euclidean) of the test sample to all samples of the training set and thus we find its $k$ nearest neighbours. The test sample is then assigned to the class to which the majority of $k$ neighbours belong.

In our research the $\mathrm{kNN}$ classifier plays the role of a criterion function ${ }^{2}$ estimating informativity of the subset of features in the following way: each sample (each company) will be assigned to a class according to its $k$ closest neighbours for the tested subset of

\footnotetext{
${ }^{1}$ Here it must be noted that the choice of explanatory variables entering the cluster analysis is by no means self-evident. Classification of companies into competitive and uncompetitive can certainly be accomplished in several ways and we can suppose that the identified groups (clusters) will differ. Discussion risks can be found in Suchánek, Špalek, 2008.

${ }^{2}$ Usually one, three or five neighboursneighbors are selected. Hence the method has three basic variants $-1 \mathrm{NN}, 3 \mathrm{NN}, 5 \mathrm{NN}$.
} 
features. Then we obtain a statistic on how many samples have been classified correctly or wrongly. The proportion of correctly (re)classified samples, evaluated for the currently tested subset of features, will be applied while searching an algorithm for the subsequent search. This will result in a subset of features yielding the most accurate classification in this sense.

The objective of the UTIA method is to find such a set of factors which jointly cause that the given group of companies will be distinguished from other groups (clusters). What is critical about this method is the joint action of the factors - established factors (variables) need not necessarily act independently. On the contrary, only in combination with other variables a company will be assigned to one of the groups. As mentioned above, the method was used for clarifying differences between companies, which the cluster analysis referred to as CC1 companies (and which are labelled as uncompetitive) and other companies - see Fig. 1. In other words, our target was to find such a set (vector) of factor, whose suitable combination of values will rank a company amongst less or more successful. Then these factors are referred to as uncompetitiveness factors.

Software application, specially developed for the needs of our research by UTIA, was used for searching the vector of factors. The application enabled relatively extensive experiments, where it was possible to vary not only the number and structure of input variables, but also the number of considered closest neighbours (variants $1 \mathrm{NN}, 3 \mathrm{NN}$, $5 \mathrm{NN}$ ). Critical for the evaluation of experiment success was the value of statistical criterion measuring the degree to which the variances between clusters found by the vector of variables (factors) are explained. In other words, if the criterion value is 0,9215 , it means more than $92 \%$ of variance explanation between cluster CC 1 and the rest of the set, using the discovered vector of twenty variables.

\section{Bivariate statistical analysis of data}

The method UTIA assumes that a found set of variables acts as a whole. Therefore only a certain combinations of variables causes that some company falls within a cluster of companies or does not fall into the given cluster of companies. Although there is no point in following a partial influence of individual variables per se, the bivariate analysis is a suitable starting point for seeking the typical combination of values in identified variables. Only the concrete values of identified factors pointing to uncompetitiveness can be used for the subsequent interpretation of results. Thus the bivariate analysis renders the results of the UTIA method more concrete and precise, because it involves not only concrete factors of (un)competitiveness, but also their values.

With regard to the character of used variables which entered the method UTIA and which were potential factors, we used mainly crosstabs for the variables acquiring discrete values (see Tables 2 - 4). Since the procedure is not suitable for continuous variables (or their average values) comparison of means and the paired t-test (see Table $1)$.

Bivariate analysis was applied not only at the end of this research but also at the beginning. Before starting with the method developed by UTIA, the number of potential factors was reduced. The reason was a low rate of response to some questions in the 
questionnaires $^{1}$. In order to narrow the resulting tier of potential variables, simple statistical methods including the bivariate method were used (they included mainly the univariate frequency analysis and correlation analysis). The selected procedure resulted in the formulation of 37 potential factors, which then became input factors for the UTIA method of statistical recognition of patterns.

\section{Results}

\section{Cluster analysis}

Fig. 1 shows the average value-weighted return on assets and the assets growth rate for each of 13 clusters of respondents in the last five years, where weight was the diminishing significance of data towards the past (i.e. weight 1 for the year 2002 and weight 5 for the year 2006). Size of the circle is proportional to the number of respondents in the given typical cluster. The dashed lines in Fig. 1 show average values of both criteria, which for ROA equal $9,0 \%$ and for the assets growth rate $15,5 \%$ (Šiška, 2009).

Together with axes the dashed lines partitioned the area of possible combinations of two principal criteria levels into nine fields. We chose the labelling of a typical cluster according to the corresponding field it is located in. Concretely the structure of cluster label is always determined by combination of three characters (XYZ) - see Šiška, 2009:

$\mathrm{X}$ - determines the category of return on assets

$\mathrm{A}=$ above average,

$\mathrm{B}=$ below average,

$\mathrm{C}=$ negative, or loss-making company

$\mathrm{Y}$ - analogically denotes categories A, B, C of assets growth

$\mathrm{Z}$ - is the cluster's serial number in the given field (1 means the most profitable cluster in the given field).

Fig. 1: Average ROA and average asset growth rate for typical clusters

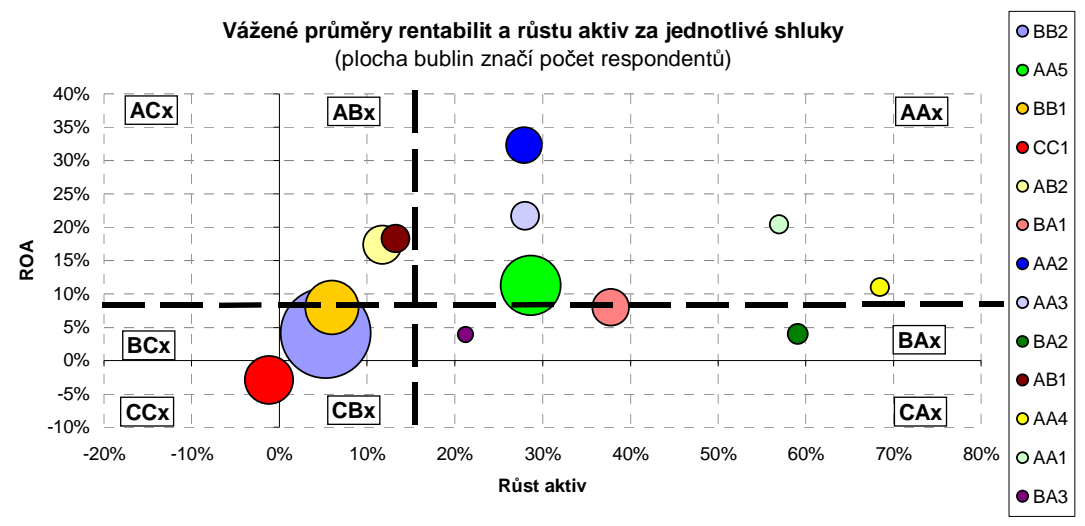

\footnotetext{
${ }^{1}$ The reason for reducing the number of variables involved in the method was also the problem of dimensionality. See Pudil, Somol, 2008.
} 
Source: Šiška, 2009

Evidently the top-performing companies are placed in clusters AAx, where there are five clusters in total. Their opposite is cluster $\mathrm{CC} 1$, which concentrates the loss-making respondents with decreasing volume of assets. Roughly average performance is reached by two clusters of companies in the field BB. These thirteen clusters represent a relatively large group that is difficult to classify. It is obvious that companies C, or CC1 are among low performing, inefficient companies. This relatively compact group of companies (that includes 42 companies, i.e. about $10 \%$ of companies in the sample) is the best candidate for comparison with other companies.

\section{Method of statistical recognition of patterns (UTIA)}

We have applied three variants of the method developed by UTIA to find the vector of variables, which could be denoted as factors of uncompetitiveness - factors, which cause the assignment of a company to the group of less efficient ones. The best results were yielded by using the method of three neighbours, where the criterion value is 0,9215 . The resulting vector includes 20 variables. ${ }^{1}$

Table 1 Found vector of variables (continuous variables)

\begin{tabular}{|c|c|c|c|}
\hline \multirow[t]{2}{*}{ Factor } & \multirow[t]{2}{*}{ Name of the variable } & \multicolumn{2}{|c|}{ Average value } \\
\hline & & Companies C & others \\
\hline F3 & Staff numbers per managerial level & 81,26 & 85,56 \\
\hline F7 & Total staff numbers in the company & 235,76 & 289,5 \\
\hline F8 & Proportion of workers with tertiary education & $10,56 \%$ & $11,42 \%$ \\
\hline F9 & Proportion of technical-economic workers & $25,2 \%$ & $29,1 \%$ \\
\hline F11* & $\begin{array}{l}\text { Average proportion of variable component of } \\
\text { salary to basic salary }\end{array}$ & $23,66 \%$ & $29,82 \%$ \\
\hline F12 & Amount allocated to fringe benefits & $6,34 \%$ & $5,48 \%$ \\
\hline F14 & Existing stability of customers (on average) & 3,81 & 3,82 \\
\hline F15 & Existing stability of suppliers (on average) & 3,84 & 3,84 \\
\hline F16 & $\begin{array}{l}\text { Average assessment of significance of criteria } \\
\text { selection for a new supplier (current state) }\end{array}$ & 3,64 & 3,58 \\
\hline F20* & Value added per employee & $270849 \mathrm{CZK}$ & $508468 \mathrm{CZK}$ \\
\hline
\end{tabular}

$*$ differences between tested groups of companies are statistically significantly different at the level $\alpha=0,05$

Source: authors

As seen from Table 1, ten factors have the character of continuous variables. The variables either acquire absolute values, if they are units of numbers of employees (factors 3 and 7) or they are expressed in financial terms (factor 20). Third group is made up of relatively expressed variables in percent (factors $8,9,11,12$ ). Remaining

\footnotetext{
${ }^{1}$ Here we must confess that the result is not the highest value of the criterion. The best explanation of differences between cluster $\mathrm{C}$ and the rest of the set is provided by the same method $3 \mathrm{NN}$ but only for four variables. The result we have selected, is in our opinion better for characterization of possible factors, which could contribute to the monitored differences. Moreover, three out of four variables from this best vector occur in our selected vector.
} 
factors 14, 15 a 16 show average assessment on the scale from 1 (low stability or importance) to 5 (high stability or importance).

Table 2 Comparison of relative frequencies of factors F1, F2 a F4

F1 Importance of creditors (as stakeholders) for a company

\begin{tabular}{|l|c|c|}
\hline \multirow{2}{*}{ Variable value } & \multicolumn{2}{|c|}{ Relative frequency of variable occurrence (in \%) } \\
\cline { 2 - 3 } & Companies C & Others \\
\hline $\mathbf{1}$ & 20 & 21,22 \\
\hline $\mathbf{3}$ & 17,5 & 17,77 \\
\hline $\mathbf{4}$ & 27,5 & 36,07 \\
\hline $\mathbf{5}$ & 20 & 16,98 \\
\hline
\end{tabular}

F2 Importance of community in the surroundings (as stakeholder)

\begin{tabular}{|l|c|c|}
\hline \multirow{2}{*}{ Variable value } & \multicolumn{2}{|c|}{ Relative frequency of variable occurrence (in \%) } \\
\cline { 2 - 3 } $\mathbf{1}$ & 12,20 & Others \\
\hline $\mathbf{2}$ & 17,07 & 24,09 \\
\hline $\mathbf{3}$ & 34,15 & 19,95 \\
\hline $\mathbf{4}$ & 31,71 & 35,49 \\
\hline $\mathbf{5}$ & 4,88 & 16,06 \\
\hline \multirow{3}{*}{ F4 Type of ownership structure } & 4,40 \\
\hline Variable value & Relative frequency of variable occurrence (in \%) \\
\cline { 2 - 3 } & Companies C & Others \\
\hline $\mathbf{1}$ & 23,81 & 21,82 \\
\hline $\mathbf{2}$ & 21,43 & 15,06 \\
\hline $\mathbf{3}$ & 9,52 & 18,18 \\
\hline $\mathbf{4}$ & 16,67 & 28,05 \\
\hline $\mathbf{5}$ & 28,57 & 16,88 \\
\hline
\end{tabular}

Source: authors

Factors F1 and F2 listed in Table 2 were rated on the scale from 1 (unimportant) to 5 (very important group). Factor F4 was rated with regard to the type of ownership structure. Value 1 represents a company owned by one person (natural person or legal person), provided that the company is not a part of a holding. Value 2 represents a company owned by one legal person where the company is a part of a holding. Value 3 represents a company, owned by a majority owner (natural or legal person) and several minority owners while the company can but need not be a part of a holding. Value 4 represents a company owned by several owners (natural persons) from the CR and the company is not a part of a holding. Value 5 represents other types of ownership structures in the company. 
Table 3 Comparison of relative frequencies of factors F5, F6, F17 and F18

F5* Members of top management are also owners (their proportion exceeds 5\%)

\begin{tabular}{|l|c|c|}
\hline \multirow{2}{*}{ Variable value } & \multicolumn{2}{|c|}{ Relative frequency of variable occurrence (\%) } \\
\cline { 2 - 3 } & Companies C & Others \\
\hline Yes & 57,89 & 37,36 \\
\hline No & 42,11 & 62,64 \\
\hline
\end{tabular}

F6* SW application - Modules SCM (supplier chain management)

\begin{tabular}{|l|l|}
\hline Variable value & Relative frequency of variable occurrence (\%)
\end{tabular}

\begin{tabular}{|l|c|c|}
\cline { 2 - 3 } & Companies C & Others \\
\hline Yes & 50 & 72,65 \\
\hline No & 50 & 27,35 \\
\hline
\end{tabular}

F17* ISO 14000

\begin{tabular}{|l|l|}
\hline Variable value & Relative frequency of variable occurrence (\%) \\
\cline { 2 - 2 } & Companies C
\end{tabular}

\begin{tabular}{|l|c|c|}
\cline { 2 - 3 } & Companies C & Others \\
\hline Yes & 18,42 & 46,70 \\
\hline No & 81,58 & 53,30 \\
\hline
\end{tabular}

F18* OHSAS 18001

\begin{tabular}{|l|c|c|}
\hline \multirow{2}{*}{ Variable value } & \multicolumn{2}{|c|}{ Relative frequency of variable occurrence ( \%) } \\
\cline { 2 - 3 } & Companies C & Others \\
\hline Yes & 5,56 & 18,71 \\
\hline No & 94,44 & 81,29 \\
\hline
\end{tabular}

* differences between tested groups of companies are statistically significantly different at the level $\alpha=0,05$

Source: authors

All factors indicated in Table 3 have a character of dichotomy (they acquire the values of yes, no). Results of all four factors were statistically significant at the level $\alpha=0,05$

Table 4 Comparison of relative frequencies of factors F10, F13 a F19

\begin{tabular}{|c|c|c|}
\hline \multicolumn{3}{|c|}{ F10 Staff turnover } \\
\hline \multirow[t]{2}{*}{ Variable value } & \multicolumn{2}{|c|}{ Relative frequency of variable occurrence (\%) } \\
\hline & Companies $\mathbf{C}$ & Others \\
\hline 1 & 16,67 & 26,18 \\
\hline 2 & 61,90 & 62,57 \\
\hline 3 & 21,43 & 11,26 \\
\hline \multicolumn{3}{|c|}{ F13 Company's business strategy } \\
\hline \multirow[t]{2}{*}{ Variable value } & \multicolumn{2}{|c|}{ Relative frequency of variable occurrence $(\%)$} \\
\hline & Companies $\mathbf{C}$ & Others \\
\hline
\end{tabular}




\begin{tabular}{|c|c|c|}
\hline 1 & 34,21 & 21,86 \\
\hline 2 & 31,58 & 28,74 \\
\hline 3 & 18,42 & 18,26 \\
\hline 4 & 15,79 & 31,14 \\
\hline \multicolumn{3}{|c|}{$\begin{array}{l}\text { F19* Classification according to the industry (Industry/Construction } \\
\text { Industry) }\end{array}$} \\
\hline & \multicolumn{2}{|c|}{ Relative frequency of variable occurrence (\%) } \\
\hline & Companies $\mathbf{C}$ & Others \\
\hline Industry & 97,62 & 78,97 \\
\hline $\begin{array}{l}\text { Construction } \\
\text { industry }\end{array}$ & 2,38 & 21,03 \\
\hline
\end{tabular}

Factors included in Table 4 are rated in a different way. Staff turnover (F10) not exceeding $2 \%$ is rated 1 , staff turnover $2-10 \%$ is rated 2 and staff turnover higher than $10 \%$ is rated 3. Firm's business strategy (F13) was rated on the scale of 1 to 5, with the following meaning: 1 for a wide range of production and customers and orientation on low prices and costs, 2 for a wide range of production and customers and orientation on specific character of products with higher prices, 3 for a narrow range of production and customers, orientation on low prices and costs and 4 for a narrow range of production and customers, orientation on specific character of products with higher prices. The last factor (F19) was used to ascertain whether surveyed companies belong to some branch of industry or to the construction industry.

\section{Discussion}

The results demonstrate that inefficient companies have a lower number of employees per a managerial level (F3). It can be caused by the fact that the companies may be smaller, and it makes them less stable both economically and financially. This corresponds with the number of employees in the company (F7), which is by about 50 persons lower in inefficient companies. Since the survey was focused mainly on large and medium companies, it is obvious that chiefly medium companies are uncompetitive.

Furthermore, inefficient companies are characterized by a lower percentage of workers with higher education (F8), even if the difference from other companies is not so big $(7,5 \%)$. It is interesting to note that the same is true about technical and economic workers (F9), where the difference is even greater $(13,4 \%)$. This group of employees also includes the management that does important and skilled work (in management, marketing, sales etc.), which cannot be performed with the same quality by blue collars or less skilled workers in low-performing companies.

In inefficient companies the average proportion of the variable component to the basic salary (F11) is also significantly lower (by nearly 21\%) than in other companies, which can partly be linked with the wage policy in companies to save labour costs and partly with the financial situation of the company (low-performing companies do not have sufficient funds to financially stimulate their employees). In may also have an impact on 
the staff turnover (F10). This can be quite similar on the average in both lowperforming and other companies, but they differ significantly in a higher number of low-performing companies, which report a high staff turnover (by more than $10 \%$ ), as opposed to a lower number of inefficient companies that report a low staff turnover (by about $10 \%$ ). Totally, the staff turnover in inefficient companies can be evaluated as higher. It cannot be changed by higher expenses on fringe benefits in inefficient companies spend (by 13,6 \% more) (F12). In comparison with F11 we can infer that employees are more interested in money in the form of salary than fringe benefits provided by the company "free of charge".

As far as the stability of customers and suppliers is concerned (F14 a F15), there is practically no difference between the two groups and both groups of companies rate their significance slightly above average. The question arises to what extent they are successful in keeping the stability. With respect to the results of other factor (especially F3, F8, F9, F11 and F10) it can be deduced that inefficient companies are less successful in this area even in spite of a slightly higher (by nearly $2 \%$ ) average rating of criteria for choosing a new supplier (F16) in low-performing companies.

Uncompetitiveness of companies in group $\mathrm{C}$ is perhaps best captured by the value added per employee (F20), which is by $46,7 \%$ lower than in other companies. It is undoubtedly one of the principal causes of ineffectiveness. Related to it is the business strategy of the company (F13), which is relatively different in low-performing companies and others. While the former are characterized by a wide range of production (nearly $65 \%$ of companies), the latter are well balanced in relation to a wide or narrow range of production ( $50.7 \%$ and. $49,3 \%$ respectively). Greatest differences exist in the orientation on a wide range of production and customers, low prices and low costs (by $36 \%$ more of inefficient companies) and alternatively the orientation on a narrow range of production and customers including specific products with a higher price (by roughly $50 \%$ fewer companies performing poorly).

Differences can also be seen in the significance attached to creditors (F1) or the community in the surroundings (F2). Both these groups are more important for inefficient companies than for other companies. If financial situation is tight then lowperforming companies are forced to get on well with their creditors (e.g. to get bridging loans etc.). The nearest community can be important if a company tries to draw attention (a kind of PR activity) with the aim to gain the competitive advantage in future. Because some funds must be spent on these activities, which can be profitable in the long term, this may be one of the causes of a bad financial performance of the firm.

Companies also differ in the factor examining whether top managers simultaneously own at least $5 \%$ of the company (F5) as is the case in most inefficient companies. The situation appears to be projected into the type of ownership structure (F4), because inefficient companies are more often owned by one person (natural or legal) regardless of the fact whether the company is a part of a holding in contrast to other companies, which are predominantly owned by several owners (regardless of their incorporation in a holding).

Inefficient companies are also characterized by a lower utilization of the SCM (F6) and a lower rate of ownership of the certificate ISO 14000 (F17) and OHSAS 180001 (F18). We can only infer that both these factors are financially demanding and low-performing 
companies may not perceive any contribution in their acquisition. Affiliation to either industry or building industry could be associated with utilization of the above module and certificates (F19), since inefficient companies are more often included in the industrial sector (by 19\%).

\section{Conclusion}

One of the most extensive statistical surveys in Czech Republic, performed by the Research Centre for Competitiveness of the Czech Economy, analyzed a sample of 432 companies. The main objective of the survey was to formulate the factors which either increase or decrease the probability that a given company will be rated as competitive. The article is focused on the second aspect: What factors lead to reducing competitiveness? The basic cluster analysis performed by Šiška (see Šiška, 2008) identified several typical clusters of companies. One of the most homogeneous groups was the cluster of least efficient companies. They are characterized by zero or negative assets growth and zero or negative value of ROA (in the past five years). We used this group of companies in an effort to find the factors, which bring about relatively lower values of financial indicators.

We found 20 qualitative characteristics, which can be the cause of this state using a rather sophisticated statistical method of pattern recognition. It was developed at UTIA ČSAV and modified in a special way for the purpose of our research.

The established characteristics mainly relate to employees (factors F3, F7, F8, F9, F10, F11, F12, F20), which proves that employees are the most important stakeholders in the company, or the stakeholders, who have the most significant impact on uncompetitiveness of the company.

On the other hand it is self-evident that uncompetitiveness is influenced by a number of characteristics typical for other stakeholders in the company. They include owners (factors F4, F5, F6), customers (factors F13, F14), suppliers (factors F15, F16), creditors (F1) as well as the community related to the company (factors F2, F17, F18). Then the only stakeholder that does not distinguish between uncompetitive and competitive firms is the state, which is not represented by a single characteristic.

Moreover, factor F19 suggests that the above findings about contributory characteristics causing uncompetitiveness should be limited mainly to industrial companies.

The conclusions result in explicit recommendations to the companies, whose economic results are in agreement with a given cluster. There is no doubt that the key to success and competitiveness is the issue of employee care and a well balanced staff structure. Nevertheless, this area must be linked with the influence of other important stakeholders of the company, especially its owners. It is interesting that uncompetitive companies attach greater importance to the community in the surroundings of the company than other, more successful companies. The reason for this as well as the analysis of other groups of companies will be the object of further research of the Centre. 


\section{References}

BLAŽEK, L. (2005). Výzkum konkurenceschopnost podniku. Aplikace stakeholderského př́istupu. In Vyvojové tendence podniků (Svazek I.). 1. vyd. Brno: MU Brno, pp. 13-28. ISBN 80-210-3847-0.

BLAŽEK, L. et. al. (2007). Konkurenceschopnost podniků. 1. vydání, Brno: Masarykova univerzita. ISBN 978-80-210-4456-2.

BLAŽEK, L. et al. (2008) Konkurenceschopnost podniků : (analýza faktorů hospodářské úspěšnosti). 1. vyd. Brno : Masarykova univerzita, 2008. 211 s. ISBN 9788021047341.

BLAŽEK, L., ČÁSTEK, O. (2009). Stakeholder approach to the competitiveness of enterprises. Národohospodářský obzor. 9(2), pp. 91-106. DOI: 10.2478/v10135-0090002-7

DONALDSON, T., PRESTON, L. E. (1995). The stakeholder theory of the corporation: Concepts, evidence, and implications. Academy of Management Review. 20(1), pp. 6591.

MIKOLÁŠ, Z. (2005). Jak zvýšit konkurenceschopnost podniku. 1. vydání, Praha: Grada Publishing. ISBN 80-247-1277-6.

PITRA, Z. (2001). Zvyšování podnikatelské výkonnosti firmy: strategický obrat $v$ podnikatelském chování. Praha: Ekopress. ISBN 8086119645.

PUDIL, P., SOMOL, P. (2006). An Overview of Feature Selection Techniques in Statistical Pattern Recognition. In Proceedings of the 16th Annual Symposium on Pattern Recogniton, Cape Town, South Africa, pp. 1-14. ISBN 0-7992-2264.

PUDIL, P., SOMOL, P. (2008). Teoretické základy využití statistických metod rozpoznávání pro vyhledání faktorů hospodářské úspěšnosti podniků. In BLAŽEK, L. et. al., Konkurenceschopnost podniků: (analýza faktorủ hospodářské úspěšnosti). Brno: Masarykova univerzita.

SLANÝ, A. et. al. (2006). Konkurenceschopnost české ekonomiky : (vývojové trendy). 1. vydání, Brno: Masarykova univerzita. ISBN 80-210-4157-9.

SUCHÁNEK, P., ŠPALEK, J. (2008). Competitiveness of Companies in the Czech Republic. The Business Review, Cambridge, 2008, 11(2), pp. 192-199.

ŠIŠKA, L. (2005). Možnosti měření a řízení efektivnosti a úspěšnosti podniku. Working Paper. 14/2005, Brno: Centrum výzkumu konkurenceschopnosti české ekonomiky. ISSN 1801-4496.

ŠIŠKA, L. (2008). Analýza finanční výkonnosti respondentů empirického šetření CVKS. Working Paper. 6/2008, Brno: Centrum výzkumu konkurenceschopnosti české ekonomiky. ISSN 1801-4496.

ŠIŠKA, L. (2009). Jak hodnotit hospodářskou úspěšnost podniku? In Ekonomický rozvoj a management regionů, 2009, (pp. 306-312). Hradec Králové: Univerzita Hradec Králové. ISBN 978-80-7041-227-5. 


\title{
COMPETITIVENESS OF CZECH ENTERPRISES: WHAT AFFECTS THE PERFORMANCE OF THE ENTERPRISE?
}

\section{Petr Suchánek, Jiří Špalek}

Ekonomicko-správní fakulta Masarykovy univerzity, katedra podnikového hospodářství, katedra veřejné ekonomie, Lipová 41a, 60200 Brno (Petr.Suchanek@econ.muni.cz; Jiri.Spalek@econ.muni.cz)

\begin{abstract}
This article is based on an empirical survey performed by the Research Centre for Competitiveness of the Czech Economy in 2007. We analyzed a sample of 432 companies. The main objective of the article is to formulate the factors which decrease the probability that a given company will be rated as competitive. Using advanced statistical methods (particularly statistical method of pattern recognition developed by UTIA ČSAV and modified in a special way for the purpose of our research) we formulate 20 qualitative characteristics, which can cause uncompetitiveness of the selected firm. These characteristics are then discussed and basic recommendations are drawn.
\end{abstract}

Key words: Competitiveness, enterprise cluster analysis, stakeholder

Abstrakt: Článek vychází z empirického šetření provedeného Centrem pro výzkum konkurenceschopnosti v roce 2007. Základem je vzorek 432 českých průmyslových podniků. Cílem příspěvku je nalézt faktory, které snižují konkurenční schopnost daného podniku. Výchozím kritériem konkurenceschopnosti je finanční úspěšnost daného podniku, prričemž podniky jsou na základě shlukové analýzy rozděleny do dvou skupin. S využitím statistické metody rozpoznávání obrazců vyvinuté a speciálně pro daný výzkum upravené pracovištěm UTIA ČSAV formulujeme 20 faktorů nekonkurenceschopnosti. Tyto faktory dále diskutujeme a na jejich základě vyvozujeme doporučení pro české podniky.

Klíčová slova: Konkurenceschopnost, podnik, shluková analýza, stakeholder

JEL classification: G30, M21

DOI: $10.2478 / v 10135-009-0003-6$ 